\title{
Aeromonas rivuli sp. nov., isolated from the upstream region of a karst water rivulet
}

\author{
M. J. Figueras, ${ }^{1}$ A. Alperi, ${ }^{1}$ R. Beaz-Hidalgo, ${ }^{1}$ E. Stackebrandt, ${ }^{2}$ \\ E. Brambilla, ${ }^{2}$ A. Monera ${ }^{3}$ and A. J. Martínez-Murcia ${ }^{3}$
}

Correspondence
M. J. Figueras
mariajose.figueras@urv.cat

\author{
${ }^{1}$ Unitat de Microbiologia, Departament de Ciències Mèdiques Bàsiques, Facultat de Medicina \\ Ciències de la Salut. IISPV. Universitat Rovira i Virgili, Reus, Spain \\ ${ }^{2}$ DSMZ-Deutsche Sammlung von Mikroorganismen und Zellkulturen GmbH, Braunschweig, \\ Germany \\ ${ }^{3}$ Molecular Diagnostics Center and Universidad Miguel Hernández, Orihuela, Spain
}

\begin{abstract}
Two freshwater isolates (WB4.1-19 ${ }^{\top}$ and WB4.4-101), sharing 99.9\% 16S rRNA gene sequence similarity, were highly related to Aeromonas sobria ( $99.7 \%$ similarity; 6 bp differences). A phylogenetic tree derived from a multi-locus phylogenetic analysis (MLPA) of the concatenated sequences of five housekeeping genes ( $g r B, r p o D$, recA, dnaJ and $g y r A ; 3684 \mathrm{bp}$ ) revealed that both strains clustered as an independent phylogenetic line next to members of Aeromonas molluscorum and Aeromonas bivalvium. The DNA-DNA reassociation value between the two new isolates was $89.3 \%$. Strain WB4.1-19 ${ }^{\top}$ had a DNA-DNA relatedness value of $<70 \%$ with the type strains of the other species tested. Phenotypic characterization differentiated the two novel strains from all other type strains of species of the genus Aeromonas. It is concluded that the two new strains represent a novel species of the genus Aeromonas, for which the name Aeromonas rivuli sp. nov. is proposed, with the type strain WB4.1-19 ${ }^{\top}\left(=\mathrm{CECT} 7518^{\top}=\mathrm{DSM}\right.$ $22539^{\top}=\operatorname{MDC} 2511^{\top}$ ).
\end{abstract}

The genus Aeromonas (family Aeromonadaceae, class Gammaproteobacteria), includes bacteria that are considered autochthonous of aquatic environments and are often associated with fish and human diseases (Martin-Carnahan \& Joseph, 2005; Figueras, 2005; Janda \& Abbott, 2010). At the time of writing, the genus includes more than 20 recognized species (Martin-Carnahan \& Joseph, 2005; Saavedra et al., 2006; Miñana-Galbis et al., 2007; Demarta et al., 2008; Martínez-Murcia et al., 2008; BeazHidalgo et al., 2009; Alperi et al., 2010b). Aeromonas group 501 has been recently described and named as Aeromonas diversa (Miñana-Galbis et al., 2010) and two further species, Aeromonas taiwanensis and Aeromonas sanarellii, have also been described recently (Alperi et al., 2010a). The taxonomy of the genus Aeromonas is considered complex when using either classical identification tools, such as phenotypic characteristics, or the 16S rRNA gene

Abbreviations: MLPA, multi-locus phylogenetic analysis; VP, VogesProskauer.

The GenBank/EMBL/DDBJ accession numbers for the $16 \mathrm{~S}$ rRNA, gyr $B, r p o D$, recA, dnaJ and gyrA gene sequences of strains WB4.1-19 ${ }^{\top}$ and WB4.4-101 are FJ976900, FJ969434, FJ969433, FJ969435, FJ969432 and FJ969436, and FJ976899, FJ969439, FJ969437, FJ969440, FJ969441 and FJ969438, respectively.

Supplementary figures and tables are available with the online version of this paper.
(Martínez-Murcia et al., 2005; Ørmen et al., 2005). 16S rRNA gene sequence analysis is considered to be a robust tool that is widely used in bacterial taxonomy. A threshold value for sequence similarity of about $97 \%$ was proposed for the latter gene, below which strains exhibit sufficiently low DNA-DNA reassociation values (i.e. $<70 \%$ ) to be considered as representing separate species (Stackebrandt \& Ebers, 2006, and references therein). Recently, based on a broader dataset, the threshold value was increased to $98.7-99.0 \%$ in order to facilitate taxonomic studies without sacrificing the quality and precision of a 'species' description (Stackebrandt \& Ebers, 2006). In the genus Aeromonas, only one species (Aeromonas simiae) shows $16 \mathrm{~S}$ rRNA gene sequence similarities below $97 \%$ (96.8\%), while many of the others show values greater than $99.0 \%$. Strains of Aeromonas bestiarum, Aeromonas salmonicida and Aeromonas piscicola possess an identical sequence for this gene (Martínez-Murcia et al., 2005; Beaz-Hidalgo et al., 2009; Alperi et al., 2010a, b). These high 16S rRNA gene sequence similarities and the microheterogeneities found in this gene hamper its utility for analysis of this genus (Alperi et al., 2008, 2010a, b).

The use of housekeeping genes has been recommended as part of a polyphasic approach for the genomic circumscription of species and as a means of differentiating taxa from neighbouring species detected by, for example, $16 \mathrm{~S}$ rRNA gene sequences (Stackebrandt et al., 2002). We have 
introduced sequence analyses of housekeeping genes ( $\mathrm{gyrB}$ and $r p o D$ ) for studies on the phylogenetic relationships between members of the genus Aeromonas (Yáñez et al., 2003; Soler et al., 2004). This approach turned out to constitute a turning point in the taxonomy of aeromonads as these genes, in common with other genes investigated recently (rpoB, dnaJ, recA and $c p n 60)$ by other authors (Küpfer et al., 2006; Nhung et al., 2007; Sepe et al., 2008; Miñana-Galbis et al., 2009), show a much higher resolution than 16S rRNA gene sequences. The analysis of housekeeping genes has not only led to some proposals for the reclassification of existing taxa (Martínez-Murcia et al., 2009), but has also enabled the recognition of novel species of the genus Aeromonas, e.g. Aeromonas aquariorum and Aeromonas tecta (Martínez-Murcia et al., 2008; Demarta et al., 2008) and, more recently, A. piscicola, A. fluvialis, A. taiwanensis and A. sanarellii (Beaz-Hidalgo et al., 2009; Alperi et al., 2010a, b).

In a recent environmental study, the taxonomic diversity of aerobic bacteria $(n=681)$ in a karst water rivulet in northern Germany (Westerhöfer Bach) was evaluated and 40 different genera and about 60 novel phylospecies were identified (Cousin et al., 2008). Fifteen of the recovered isolates, belonging to the genus Aeromonas on the basis of partial 16S rRNA gene sequences (432 bp), were sent to our laboratory for further molecular characterization. The present communication describes the polyphasic approach adopted for the classification of a novel species of the genus Aeromonas.

All 15 isolates were cultured on sheep blood agar at $30{ }^{\circ} \mathrm{C}$ and DNA was extracted from single colonies using InstaGene Matrix (Bio-Rad Laboratories). The conditions for $r p o D(820 \mathrm{bp})$ and 16S rRNA gene (1503 bp) sequence analysis, including primers, amplification conditions and sequencing, were as previously described (Martínez-Murcia et al., 1992; Soler et al., 2004). The sequences obtained were aligned independently with the sequences of the type and reference strains of all the members of the genus Aeromonas taken from our in-house database (constructed with our own sequences) and those that are available in GenBank, using the CLUSTAL_X program version 1.8 (Thompson et al., 1997). Genetic distances were obtained using Kimura's two-parameter model (Kimura, 1980). Evolutionary trees were constructed by the neighbourjoining method (Saitou \& Nei, 1987) using the MEGA4 program (Tamura et al., 2007) and maximum-parsimony method (for the 16S rRNA gene) using PAUP* version $4.0 \mathrm{~b} 10$ (Swofford, 2002). The stability of the relationships was assessed by bootstrapping (1000 replicates).

The phylogenetic analysis based on the $r p o D$ gene revealed that 13 of the 15 strains belonged to recognized species of the genus Aeromonas, while two strains (WB4.1-19 $9^{\mathrm{T}}$ and WB4.4-101) grouped as an individual lineage within the $A$. molluscorum/A. bivalvium cluster (data not shown). The two novel isolates shared $98.6 \% r p o D$ gene sequence similarity ( $9 \mathrm{bp}$ differences between their sequences).
Sequence similarity with the closest species, A. molluscorum, was $94.3 \%$ for strain WB4.1-19 ${ }^{\mathrm{T}}$ and $94.5 \%$ for strain WB4.1-101. These values are below the minimum intra-species similarity of $97.4 \%$ previously established for the $r p o D$ gene in the genus Aeromonas (Soler et al., 2004).

The almost complete 16S rRNA gene (1503 bp) was sequenced from both novel strains and revealed that the strains were highly related to each other $(99.9 \%$ similarity; $2 \mathrm{bp}$ differences) sharing a very high gene sequence similarity (99.7\%) with Aeromonas sobria NCIMB $12065^{\mathrm{T}}$. These results were in agreement with those obtained at the DSMZ laboratory (Braunschweig, Germany) using partial sequences (432 bp) of the $16 \mathrm{~S}$ rRNA gene. The similarities found for the two novel strains were in line with those shown by other species and indicated that the 16S rRNA gene threshold value for delineation of species of the genus Aeromonas (without considering those that show $100 \%$ similarity) should be $99.5-99.7 \%$, which is higher than the new values of 98.7-99.0\% recently proposed by Stackebrandt \& Ebers (2006).

In the phylogenetic trees constructed using the $16 \mathrm{~S}$ rRNA gene sequences, the two new isolates clustered next to $A$. sobria NCIMB $12065^{\mathrm{T}}$. This association was only supported by low bootstrap values $(<50 \%)$ no matter whether the neighbour-joining (Fig. 1) or maximum-parsimony algorithms (see Supplementary Fig. S1 in IJSEM Online) were used to determine phylogeny. Chromatogram analysis of the 16S rRNA gene sequences of both strains showed microheterogeneities in two positions (1011 and 1018) for strain WB4.1-19 ${ }^{\mathrm{T}}$ and in four positions $(258,469,1355$, 1357) for strain WB4.4-101 (see Supplementary Table S1). Microheterogeneities have been described for other species of the genus Aeromonas (Alperi et al., 2008, 2010a, b).

The multi-locus phylogenetic analysis (MLPA) involved sequencing the gyrB (923 bp), rpoD (652 bp), recA (600 bp), dnaJ (800 bp) and gyrA (709 bp) genes. A phylogenetic tree was constructed with the concatenated sequences of these five genes $(3684 \mathrm{bp})$. This analysis was performed at the Molecular Diagnostic Center (MDC), Orihuela, Spain, as described by Alperi et al. (2010a).

The MLPA tree revealed, in agreement with all five singlegene phylogenies and in contrast to that of the 16S rRNA gene, that strains WB4.1-19 ${ }^{\mathrm{T}}$ and WB4.4-101 were not phylogenetically related to $A$. sobria, but appeared as an independent branch in a cluster that included A. molluscorum and A. bivalvium (Fig. 2). Species delineation based on the analysis of five housekeeping genes was recommended by the ad-hoc committee (Stackebrandt et al., 2002), but only the papers that described the species $A$. fluvialis (Alperi et al., 2010b) and A. taiwanensis and A. sanarellii from clinical isolates (Alperi et al., 2010a), have complied with this recommendation.

DNA-DNA reassociation experiments were performed between the two novel isolates and between strain 


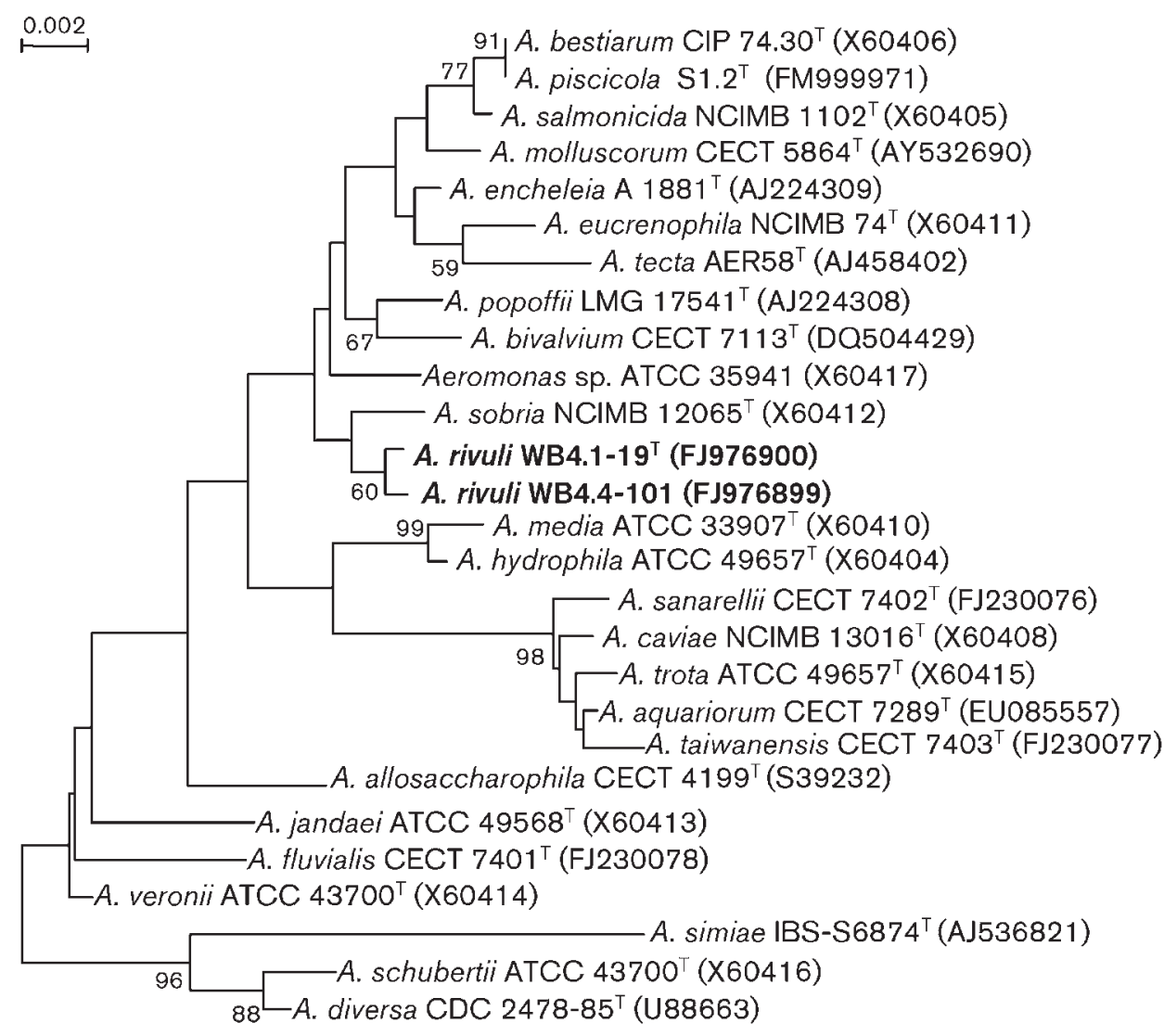

Fig. 1. Unrooted neighbour-joining phylogenetic tree derived from the $16 \mathrm{~S}$ rRNA gene sequences showing the relationships of strains WB4.1-19 ${ }^{\top}$ and WB4.4-101 with all other species of the genus Aeromonas. Numbers at nodes indicate bootstrap values $>50 \%$ (percentage of 1000 replicates). Bar, 0.002 estimated nucleotide substitutions per site.

WB4.1-19 ${ }^{\mathrm{T}}$ and the type strains of the closest species, A. sobria, A. molluscorum and A. bivalvium, as well as with A. bestiarum, A. encheleia, A. eucrenophila, A. piscicola, A. popoffii, A. salmonicida and A. tecta. DNA extraction and DNA-DNA reassociation experiments were conducted as previously described (Alperi et al., 2010b). The DNA-DNA reassociation value between strains WB4.1-19 ${ }^{\mathrm{T}}$ and WB4.4101 was $89.5 \%( \pm 6.5 \%)$, while the type strains of the other species of the genus Aeromonas showed values below the $70 \%$ threshold established for species delineation (Stackebrandt et al., 2002; see Supplementary Table S2).

Optimal growth temperature and $\mathrm{pH}$ were determined in tryptic soy broth (TSB, Difco) after 24 h by optical density. Cell sizes, morphologies and the presence of flagella were determined by electron microscopy using previously described methods (Collado et al., 2009). Both strains were straight, non-spore-forming, non-encapsulated rods that were motile by means of polar flagella (see Supplementary Fig. S2).

The cultural characteristics of strains WB4.1-19 $9^{\mathrm{T}}$ and WB4.4-101, i.e. the size and colour of colonies and production of a brown diffusible pigment, were determined on tryptic soy agar (TSA, Difco) at $30{ }^{\circ} \mathrm{C}$ for $24 \mathrm{~h}$.
Sheep blood agar (Biomedics) was used to evaluate haemolysis under the same conditions. Twenty eight phenotypic tests selected from Abbott et al. (2003) and also performed in a previous study (Alperi et al., 2010b) were used for the characterization of strains WB4.1-19 ${ }^{\mathrm{T}}$ and WB4.4-101. In addition, tests were performed to determine the utilization of L-arabinose, L-histidine, Lproline, DL-lactate and salicin as carbon sources and for the hydrolysis of starch. All tests were conducted in triplicate at $30{ }^{\circ} \mathrm{C}$. Some tests were further confirmed using commercial identification kits (API 20NE and API 20E; bioMérieux). Additional tests included in the latter kits, together with the assimilation/oxidation reactions of 49 carbohydrates using the API 50CH kit (bioMérieux) were also considered. Phenotypic characteristics that differentiated both new isolates from other species of the genus Aeromonas are presented in Table 1. All type strains of recognized species of the genus Aeromonas, including the recently described members, were tested (Table 1) under identical conditions to those used for strains WB4.1-19 and WB4.4-101.

Interestingly the two novel isolates showed phenotypic similarity with A. molluscorum as they were the only taxa 


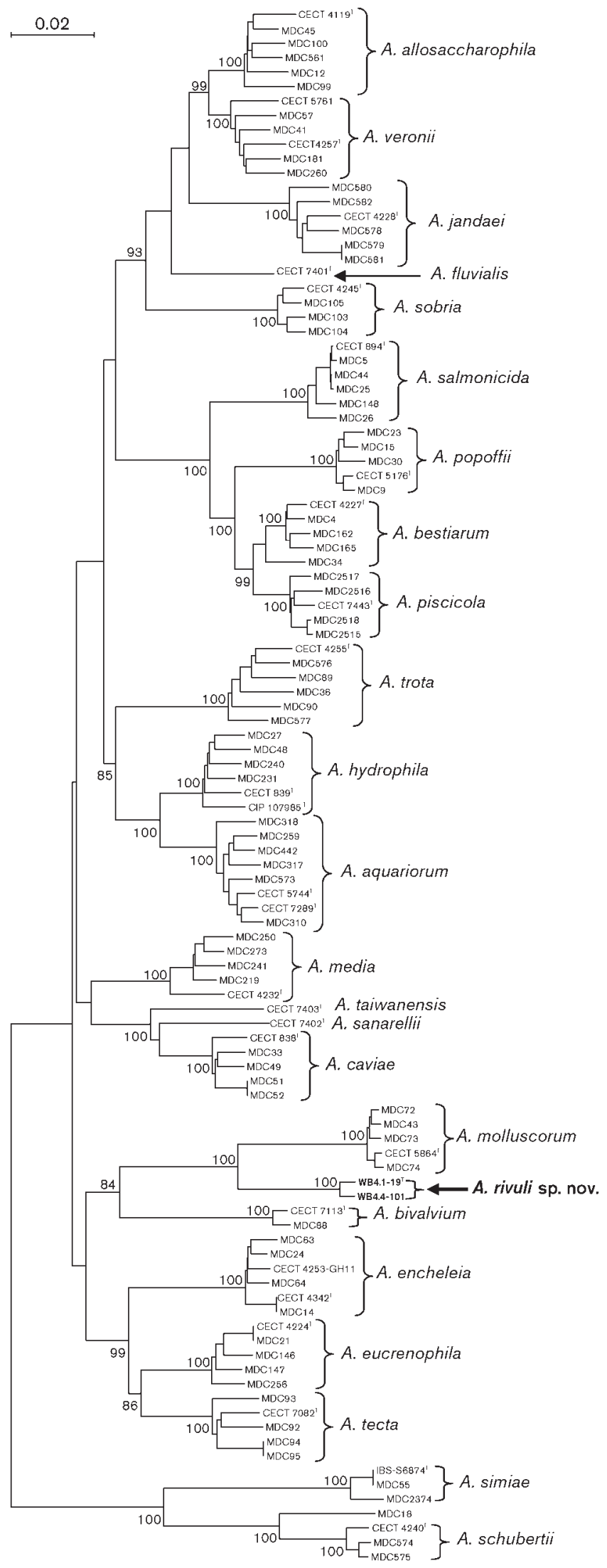

Fig. 2. Unrooted neighbour-joining phylogenetic tree derived from the MLPA of concatenated sequences of five housekeeping genes ( $g y r B, r p o D, \operatorname{rec} A, d n a J$ and $g y r A ; 3684 \mathrm{bp}$ ) showing the relationships of strains WB4.1-19 ${ }^{\top}$ and WB4.4-101 with all other species of the genus Aeromonas. Numbers at nodes indicate bootstrap values $>70 \%$ (percentage of 1000 replicates). Bar, 0.02 estimated nucleotide substitutions per site.

that all gave a negative result in tests for indole, VogesProskauer (VP) reaction, gas from glucose and for ornithine- and lysine decarboxylase. The characteristics that differentiated the novel isolates from A. molluscorum were their ability to hydrolyse starch, but not to use or produce acid from L-arabinose. Other useful tests to differentiate the two novel strains from other species of the genus Aeromonas include their inability to produce indole, gas from D-glucose, VP, lysine decarboxylase and $\beta$-haemolysis from sheep blood agar (Table 1).

Based on molecular and phenotypic evidence, it is concluded that strains WB4.1-19 ${ }^{\mathrm{T}}$ and WB4.4-101 represent a novel species of the genus Aeromonas, for which the name Aeromonas rivuli sp. nov. is proposed.

\section{Description of Aeromonas rivuli sp. nov.}

Aeromonas rivuli (ri'vu.li. L. gen. masc. n. rivuli of/from a rivulet, a small creek).

Cells are Gram-negative, non-spore-forming motile rods with a polar flagellum and are $2.0-2.5 \mu \mathrm{m}$ long and $0.5-$ $0.7 \mu \mathrm{m}$ wide. Oxidase and catalase-positive, reduces nitrates to nitrites and is resistant to the vibriostatic agent $\mathrm{O} / 129(150 \mu \mathrm{g})$. Colonies on TSA are opaque, beige in colour and $2.0-2.5 \mathrm{~mm}$ in diameter after $48 \mathrm{~h}$ incubation at $30{ }^{\circ} \mathrm{C}$ and $1.0-2.0 \mathrm{~mm}$ at $37^{\circ} \mathrm{C}$. No brown diffusible pigment is produced on TSA at $25{ }^{\circ} \mathrm{C}$ or $30{ }^{\circ} \mathrm{C}$. No haemolysis is observed on sheep blood agar at $30{ }^{\circ} \mathrm{C}$. Growth occurs at $7-37{ }^{\circ} \mathrm{C}$ and at $0-3 \% \mathrm{NaCl}(\mathrm{w} / \mathrm{v})$. Optimal growth is at $30{ }^{\circ} \mathrm{C}$ and at $\mathrm{pH} 8.7-9.0$ after $24 \mathrm{~h}$ on TSB. Positive for the $\beta$-galactosidase test, $\mathrm{ADH}$, hydrolysis of aesculin, gelatin, starch, arbutin, Tween 80 and DNA. Negative result in tests for ornithine- and lysine decarboxylase, VP, production of indole from tryptophan, gas from glucose, hydrogen sulphide from cysteine and hydrolysis of elastin. Utilization of citrate is variable. Able to utilize glycerol, D-galactose, maltose, starch, glycogen, sucrose, L-histidine, L-proline, salicin and D-mannitol, but not DLlactate, L-arabinose, potassium gluconate, potassium 2ketogluconate or potassium 5-ketogluconate. Acid is produced from glycerol (only with API $50 \mathrm{CH}$ ), D-ribose, D-galactose, D-glucose, D-fructose, D-mannose, D-mannitol, $\mathrm{N}$-acetylglucosamine, salicin, maltose, sucrose and trehalose. Does not produce acid from erythritol, D-arabinose, Larabinose, D-xylose, L-xylose, D-adonitol, methyl $\beta$-D-xylopyranoside, L-sorbose, L-rhamnose, dulcitol, inositol, D-sorbitol, methyl $\alpha$-D-mannopyranoside, methyl $\alpha$-D-glucopyranoside, amygdalin, lactose, melibiose, inulin, melezitose, 
Table 1. Key phenotypic characteristics that differentiate strains WB4.1-19 ${ }^{\top}$ and WB4.4-101 from other species of the genus Aeromonas

Taxa: 1, A. rivuli; 2, A. hydrophila; 3, A. bestiarum; 4, A. salmonicida; 5, A. caviae; 6, A. media; 7, A. eucrenophila; 8, A. sobria; 9, A. veronii biovar sobria; 10, A. jandaei; 11 , A. veronii biovar veronii; 12, A. schubertii; 13, A. trota; 14, A. encheleia; 15, A. allosaccharophila; 16, A. popoffii; 17, A. simiae (data from Harf-Monteil et al., 2004); 18, A. molluscorum (Miñana-Galbis et al., 2004); 19, A. bivalvium (Miñana-Galbis et al., 2007); 20, A. aquariorum (Martínez Murcia et al., 2008); 21, A. tecta (Demarta et al., 2008); 22, A. fluvialis (Alperi et al., 2010b); 23, A. piscicola (Beaz-Hidalgo et al., 2009); 24, A. taiwanensis (Alperi et al., 2010a); 25, A. sanarellii (Alperi et al., 2010a). +, 85-100\% of strains positive; -, 0-15\% of strains positive; v, 16-84\% of strains positive. All tests were performed for type strains and the results are expressed in parentheses as $(+)$ or $(-)$; ND, no data available; ODC, ornithine decarboxylase; LDC, lysine decarboxylase. Data for species $1-16$ were obtained from Abbott et al. (2003) with the exception of tests indicated as ND, these authors performed tests at $35^{\circ} \mathrm{C}$, with the exceptions of A. popoffii and A. sobria which were at $25{ }^{\circ} \mathrm{C}$. Tests for taxa $17,21,22,24$ and 25 were performed at $30^{\circ} \mathrm{C}$ (as in the present study). Tests for taxa 18,20 and 23 were performed at $25{ }^{\circ} \mathrm{C}$. Tests for taxon 19 were performed at $25-30{ }^{\circ} \mathrm{C}$.

\begin{tabular}{|c|c|c|c|c|c|c|c|c|c|c|c|c|c|c|c|c|c|c|c|c|c|c|c|c|c|}
\hline Characteristic & 1 & 2 & 3 & 4 & 5 & 6 & 7 & 8 & 9 & 10 & 11 & 12 & 13 & 14 & 15 & 16 & 17 & 18 & 19 & 20 & 21 & 22 & 23 & 24 & 25 \\
\hline$\beta$-Haemolysis & - & $+(+)$ & $+(+)$ & $v(+)$ & $\mathrm{v}(-)$ & $\mathrm{v}(-)$ & $+(+)$ & $-(+)$ & $+(+)$ & $+(+)$ & $+(+)$ & $\mathrm{v}(-)$ & $\mathrm{v}(+)$ & $\mathrm{v}(+)$ & $\mathrm{v}(-)$ & $-(-)$ & $-(-)$ & $v^{*}(-)$ & $-{ }^{*}(-)$ & $\mathrm{ND}(+)$ & $+(+)$ & $-(-)$ & $+(+)$ & $-(-)$ & $-(-)$ \\
\hline Indole & - & $+(+)$ & $+(+)$ & $+(-)$ & $v(+)$ & $+(+)$ & $+(+)$ & $+(+)$ & $+(+)$ & $+(+)$ & $+(+)$ & $-(-)$ & $+(+)$ & $+(+)$ & $+(+)$ & $\mathrm{v}(-)$ & $-(-)$ & $-(-)$ & $+(+)$ & $+(+)$ & $-(-)$ & $+(+)$ & $+(+)$ & $+(+)$ & $+(+)$ \\
\hline VP & - & $+(+)$ & $\mathrm{v}(+)$ & $\mathrm{v}(-)$ & $-(-)$ & $-(-)$ & $-(-)$ & $-(-)$ & $+(+)$ & $+(+)$ & $\mathrm{v}(-)$ & $\mathrm{v}(-)$ & $-(-)$ & $-(-)$ & $-(-)$ & $+(+)$ & $-(-)$ & $-(-)$ & $-(-)$ & $-\dagger(-)$ & $v(+)$ & $-(-)$ & $+(+)$ & $-(-)$ & $-(-)$ \\
\hline ODC & - & $-(-)$ & $-(-)$ & $-(-)$ & $-(-)$ & $-(-)$ & $-(-)$ & $-(-)$ & $-(-)$ & $-(-)$ & $+(+)$ & $-(-)$ & $-(-)$ & $-(-)$ & $\mathrm{v}(-)$ & $-(-)$ & $-(-)$ & $-(-)$ & $-(-)$ & $-(-)$ & $-(-)$ & $-(-)$ & $-(-)$ & $-(-)$ & $-(-)$ \\
\hline LDC & - & $+(+)$ & $\mathrm{v}(+)$ & $\mathrm{v}(-)$ & $-(-)$ & $-(-)$ & $-(-)$ & $+(+)$ & $+(+)$ & $+(+)$ & $+(+)$ & $\mathrm{v}(-)$ & $+(+)$ & $-(-)$ & $+(+)$ & $-(-)$ & $+(+)$ & $-(-)$ & $+(+)$ & $+(+)$ & $\mathrm{v}(+)$ & $-(-)$ & $+(+)$ & $-(-)$ & $-(-)$ \\
\hline Glucose (gas) & - & $+(+)$ & $\mathrm{v}(+)$ & $\mathrm{v}(-)$ & $-(-)$ & $-(-)$ & $\mathrm{v}(+)$ & $\mathrm{v}(+)$ & $+(+)$ & $+(+)$ & $+(+)$ & $-(-)$ & $\mathrm{v}(+)$ & $\mathrm{v}(+)$ & $+(+)$ & $+(+)$ & $-(-)$ & $-(-)$ & $-(-)$ & $+(+)$ & $+(+)$ & $+(+)$ & $+(+)$ & $-(-)$ & $-(-)$ \\
\hline \multicolumn{26}{|l|}{ Hydrolysis of: } \\
\hline Aesculin & + & $+(+)$ & $\mathrm{v}(+)$ & $+(+)$ & $\mathrm{v}(+)$ & $\mathrm{v}(+)$ & $\mathrm{v}(+)$ & $-(-)$ & $-(-)$ & $-(-)$ & $+(+)$ & $-(-)$ & $-(-)$ & $\mathrm{v}(+)$ & $\mathrm{v}(+)$ & $-(-)$ & $\mathrm{v}(-)$ & $+(+)$ & $+(+)$ & $+(+)$ & $\mathrm{v}(+)$ & $-(-)$ & $+(+)$ & $+(+)$ & $+(+)$ \\
\hline Starch & + & $+末(+)$ & $\mathrm{ND}(+)$ & $\mathrm{ND}(+)$ & $+末(+)$ & $+\$(+)$ & $\mathrm{ND}(+)$ & $+\ddagger(+)$ & $\mathrm{ND}(+)$ & $\mathrm{ND}(+)$ & $\mathrm{ND}(+)$ & $\mathrm{ND}(+)$ & $\mathrm{ND}(+)$ & $\operatorname{vll}(+)$ & $\mathrm{ND}(+)$ & $+9(+)$ & $\mathrm{ND}(+)$ & $-(-)$ & $+(+)$ & $+(+)$ & $\mathrm{ND}(+)$ & $\mathrm{ND}(-)$ & $+(+)$ & $+(+)$ & $+(+)$ \\
\hline \multicolumn{26}{|l|}{ Acid from: } \\
\hline Glycerol & -\# & $+(+)$ & $+(+)$ & $+(+)$ & $\mathrm{v}(-)$ & $\mathrm{v}(+)$ & $-(-)$ & $+(+)$ & $+(+)$ & $+(+)$ & $+(+)$ & $-(-)$ & $\mathrm{v}(+)$ & $+(+)$ & $+(+)$ & $+(+)$ & $+(+)$ & $+(+)$ & $+(+)$ & $+(+)$ & $+(+)$ & $+(+)$ & $+(+)$ & $+(+)$ & $+(+)$ \\
\hline Sucrose & + & $+(+)$ & $+(+)$ & $+(+)$ & $+(+)$ & $+(+)$ & $\mathrm{v}(+)$ & $+(+)$ & $+(+)$ & $-(-)$ & $+(+)$ & $-(-)$ & $\mathrm{v}(-)$ & $v(+)$ & $+(+)$ & $-(-)$ & $+(+)$ & $+(+)$ & $+(+)$ & $+(+)$ & $-(-)$ & $+(+)$ & $+(+)$ & $+(+)$ & $+(+)$ \\
\hline L-Arabinose & - & $\mathrm{v}(+)$ & $+(+)$ & $+(+)$ & $+(+)$ & $+(+)$ & $\mathrm{v}(+)$ & $-(-)$ & $-(+)$ & $-(-)$ & $-(-)$ & $-(-)$ & $-(-)$ & $-(-)$ & $\mathrm{v}(+)$ & $\mathrm{v}(+)$ & $-(-)$ & $+(+)$ & $+(+)$ & $-(-)$ & $-(-)$ & $-(-)$ & $-(-)$ & $+(+)$ & $+(+)$ \\
\hline Salicin & + & $\mathrm{v}(-)$ & $\mathrm{v}(+)$ & $\mathrm{v}(-)$ & $\mathrm{v}(+)$ & $\mathrm{v}(+)$ & $\mathrm{v}(-)$ & $-(-)$ & $-(-)$ & $-(-)$ & $+(+)$ & $-(-)$ & $-(-)$ & $-(+)$ & $-(-)$ & $-(-)$ & $-(-)$ & $\mathrm{ND}(+)$ & $+(+)$ & $+(+)$ & $\mathrm{v}(-)$ & $+(+)$ & $+(+)$ & $+(+)$ & $+(+)$ \\
\hline Lactose & - & $\mathrm{v}(-)$ & $-(-)$ & $+(-)$ & $\mathrm{v}(-)$ & $v(+)$ & $-(+)$ & $-(-)$ & $-(-)$ & $-(-)$ & $\mathrm{v}(-)$ & $-(-)$ & $-(-)$ & $-(-)$ & $-(-)$ & $-(-)$ & $-(-)$ & $-(-)$ & $-(-)$ & $-(-)$ & $-(-)$ & $+(+)$ & $-(-)$ & $-(-)$ & $-(-)$ \\
\hline \multicolumn{26}{|l|}{ Utilization of: } \\
\hline DL-Lactate & - & $\mathrm{v}(+)$ & $-(-)$ & $-(-)$ & $+(-)$ & $\mathrm{v}(+)$ & $-(-)$ & $-(-)$ & $-(-)$ & $-(-)$ & $-(-)$ & $\mathrm{v}(-)$ & $+(+)$ & $-(-)$ & $-(-)$ & $\mathrm{v}(+)$ & $\mathrm{ND}(-)$ & $\mathrm{v}(-)$ & $+(+)$ & $-(-)$ & $-(-)$ & $\mathrm{ND}(-)$ & $-(-)$ & $\mathrm{ND}(+)$ & $\mathrm{ND}(+)$ \\
\hline L-Arabinose & - & $v^{* *}(+)$ & $\mathrm{ND}(+)$ & $-* *(-)$ & $+* *(+)$ & $+* *(+)$ & $+* *(+)$ & $-* *(-)$ & $-* *(+)$ & $-* *(-)$ & $-* *(+)$ & $-* *(-)$ & $-* *(-)$ & $-* *(-)$ & $+* *(+)$ & $\mathrm{ND}(+)$ & $\mathrm{ND}(+)$ & $+(+)$ & $+(+)$ & $\mathrm{ND}(-)$ & $-(-)$ & $-(-)$ & $\mathrm{ND}(-)$ & $+(+)$ & $+(+)$ \\
\hline
\end{tabular}

${ }^{\star}$ Result from Demarta et al. (2008), performed at $30{ }^{\circ} \mathrm{C}$.

$\dagger$ VP negative result was taken from the species description of Martínez-Murcia et al. (2008) and not from the table where there was an later erratum, $(+)$.

$\ddagger$ Result from Miñana Galbis et al. (2002), performed at $25^{\circ} \mathrm{C}$

$\S$ Result from Allen et al. (1983), performed at $22^{\circ} \mathrm{C}$.

IIResult from Esteve et al. (1995), test performed at $28^{\circ} \mathrm{C}$.

Tesult from Huys et al. (1997), test performed at $28^{\circ} \mathrm{C}$.

\#Acid production from glycerol was negative when determined in tube but positive when tested by API $50 \mathrm{CH}$.

${ }^{*}$ Result from Valera \& Esteve (2002), tests performed at $28^{\circ} \mathrm{C}$. 
raffinose, xylitol, gentiobiose, turanose, D-lyxose, D-tagatose, D-fucose, L-fucose, D-arabitol or L-arabitol. Production of acid from cellobiose is variable. The API 20NE and API 20E profiles for strains WB4.1-19 ${ }^{\mathrm{T}}$ and WB4.1-101 were 5576354 and 3006167 , respectively.

The type strain, WB4.1-19 ${ }^{\mathrm{T}} \quad\left(=\mathrm{CECT} \quad 7518^{\mathrm{T}}=\mathrm{DSM}\right.$ $22539^{\mathrm{T}}=$ MDC $2511^{\mathrm{T}}$ ), was isolated from a karst hard water creek, Westerhöfer Bach, located at the north-western slope of the Harz Mountain, Lower Saxony, Germany. The isolation site was $350 \mathrm{~m}$ downstream from the discharge site.

\section{Acknowledgements}

The DSMZ work was part of the Research Unit 571 'Geobiology of Organo- and Biofilms' funded by the German Research Foundation (Sta 184/19-2; DFG-FOR 571; publication 45). The MDC work was partly supported by Grant IMIDTA/2007/68 from IMPIVA, Generalitat Valenciana, Spain. Part of this work was also supported by funds from the European Commission for the HEALTHY WATER Project (FOOD-CT-2006-036306). However, the authors are solely responsible for the content of this publication and it does not represent the opinion of the European Commission. The European Commission is not responsible for any use that might be made of data appearing therein.

\section{References}

Abbott, S. L., Cheung, W. K. \& Janda, J. M. (2003). The genus Aeromonas: biochemical characteristics, atypical reactions, and phenotypic identification schemes. J Clin Microbiol 41, 2348-2357.

Allen, D. A., Austin, B. \& Colwell, R. R. (1983). Aeromonas media, a new species isolated from river water. Int J Syst Evol Microbiol 33, 599-604.

Alperi, A., Figueras, M. J., Inza, I. \& Martínez-Murcia, A. J. (2008). Analysis of $16 \mathrm{~S}$ rRNA gene mutations in a subset of Aeromonas strains and their impact in species delineation. Int Microbiol 11, 185-194.

Alperi, A., Martínez-Murcia, A. J., Ko, W.C., Monera, A., Saavedra, M. J. \& Figueras, M. J. (2010a). Aeromonas taiwanensis sp. nov. and Aeromonas sanarellii sp. nov., two new clinical species from Taiwan. Int J Syst Evol Microbiol 60, 2048-2055.

Alperi, A., Martínez-Murcia, A. J., Monera, A., Saavedra, M. J. \& Figueras, M. J. (2010b). Aeromonas fluvialis sp. nov., isolated from Spanish river. Int J Syst Evol Microbiol 60, 72-77.

Beaz-Hidalgo, R., Alperi, A., Figueras, M. J. \& Romalde, J. L. (2009). Aeromonas piscicola sp. nov., isolated from diseased fish. Syst Appl Microbiol 32, 471-479.

Brosius, J., Palmer, M. L., Kennedy, P. J. \& Noller, H. F. (1978). Complete nucleotide sequence of a $16 \mathrm{~S}$ ribosomal RNA gene from Escherichia coli. Proc Natl Acad Sci U S A 75, 4801-4805.

Collado, L., Cleenwerck, I., Van Trappen, S., De Vos, P. \& Figueras, M. J. (2009). Arcobacter mytili sp. nov., an indoxyl acetate-hydrolysis negative bacterium isolated from mussels. Int J Syst Evol Microbiol 59, 1391-1396.

Cousin, S., Brambilla, E., Yang, J. \& Stackebrandt, E. (2008). Culturable aerobic bacteria from the upstream region of a karst water rivulet. Int Microbiol 11, 91-100.

Demarta, A., Küpfer, M., Riegel, P., Harf-Monteil, C., Tonolla, M., Peduzzi, R., Monera, A., Saavedra, M. J. \& Martínez-Murcia, A. J. (2008). Aeromonas tecta sp. nov., isolated from clinical and environmental sources. Syst Appl Microbiol 31, 278-286.
Esteve, C., Gutiérrez, M. C. \& Ventosa, A. (1995). Aeromonas encheleia sp. nov., isolated from European eels. Int J Syst Bacteriol 45, 462-466.

Figueras, M. J. (2005). Clinical relevance of Aeromonas. Rev Med Microbiol 16, 145-153.

Harf-Monteil, C., Fleche, A. L., Riegel, P., Prevost, G., Bermond, D., Grimont, P. A. \& Monteil, H. (2004). Aeromonas simiae sp. nov., isolated from monkey faeces. Int J Syst Evol Microbiol 54, 481-485.

Huys, G., Kämpfer, P., Altwegg, M., Kersters, I., Lamb, A., Coopman, R., Lüthy-Hottenstein, J., Vancanneyt, M., Janssen, P. \& Kersters, K. (1997). Aeromonas popoffii sp. nov., a mesophilic bacterium isolated from drinking water production plants and reservoirs. Int J Syst Bacteriol 47, 1165-1171.

Janda, J. M. \& Abbott, S. L. (2010). The genus Aeromonas: taxonomy, pathogenicity, and infection. Clin Microbiol Rev 23, 35-73.

Kimura, M. (1980). A simple method for estimating evolutionary rates of base substitutions through comparative studies of nucleotide sequences. J Mol Evol 16, 111-120.

Küpfer, M., Kuhnert, P., Korczak, B. M., Peduzzi, R. \& Demarta, A. (2006). Genetic relationships of Aeromonas strains inferred from 16S rRNA, gyrB and $r p o B$ gene sequences. Int J Syst Evol Microbiol 56, 2743-2751.

Martin-Carnahan, A. \& Joseph, S. W. (2005). Order XII. Aeromonadales ord. nov. In Bergey's Manual of Systematic Bacteriology, 2nd edn, vol. 2B, p. 556. Edited by D. J. Brenner, N. R. Krieg, J. T. Staley \& G. M. Garrity. New York: Springer.

Martínez-Murcia, A. J., Benlloch, S. \& Collins, M. D. (1992). Phylogenetic interrelationships of members of the genera Aeromonas and Plesiomonas as determined by $16 \mathrm{~S}$ ribosomal DNA sequencing: lack of congruence with results of DNA-DNA hybridizations. Int J Syst Bacteriol 42, 412-421.

Martínez-Murcia, A. J., Soler, L., Saavedra, M. J., Chacón, M. R., Guarro, J., Stackebrandt, E. \& Figueras, M. J. (2005). Phenotypic, genotypic, and phylogenetic discrepancies to differentiate Aeromonas salmonicida from Aeromonas bestiarum. Int Microbiol 8, 259-269.

Martínez-Murcia, A. J., Saavedra, M. J., Mota, V. R., Maier, T., Stackebrandt, E. \& Cousin, S. (2008). Aeromonas aquariorum sp. nov., isolated from aquaria of ornamental fish. Int $J$ Syst Evol Microbiol 58, 1169-1175.

Martínez-Murcia, A. J., Monera, A., Alperi, A., Figueras, M. J. \& Saavedra, M. J. (2009). Phylogenetic evidence suggests that strains of Aeromonas hydrophila subsp. dhakensis belong to the species Aeromonas aquariorum sp. nov. Curr Microbiol 58, 76-80.

Miñana-Galbis, D., Farfán, M., Lorén, J. G. \& Fusté, M. C. (2002). Biochemical identification and numerical taxonomy of Aeromonas spp. isolated from environmental and clinical samples in Spain. J Appl Microbiol 93, 420-430.

Miñana-Galbis, D., Farfán, M., Fusté, M. C. \& Lorén, J. G. (2004). Aeromonas molluscorum sp. nov., isolated from bivalve molluscs. Int $\mathrm{J}$ Syst Evol Microbiol 54, 2073-2078.

Miñana-Galbis, D., Farfán, M., Fusté, M. C. \& Lorén, J. G. (2007). Aeromonas bivalvium sp. nov., isolated from bivalve molluscs. Int $J$ Syst Evol Microbiol 57, 582-587.

Miñana-Galbis, D., Urbizu-Serrano, A., Farfán, M., Fusté, M. C. \& Lorén, G. (2009). Phylogenetic analysis and identification of Aeromonas species based on sequencing of the cpn60 universal target. Int J Syst Evol Microbiol 59, 1976-1983.

Miñana-Galbis, D., Farfán, M., Gaspar Lorén, J. \& Fusté, M. C. (2010). Proposal to assign Aeromonas diversa sp. nov. as a novel species designation for Aeromonas group 501. Syst Appl Microbiol 33, 15-19. 
Nhung, P. H., Hata, H., Ohkusu, K., Noda, M., Shah, M. M., Goto, K. \& Ezaki, T. (2007). Use of the novel phylogenetic marker $d n a J$ and DNA-DNA hybridization to clarify interrelationships within the genus Aeromonas. Int J Syst Evol Microbiol 57, 1232-1237.

Ørmen, O., Granum, P. E., Lassen, J. \& Figueras, M. J. (2005). Lack of agreement between biochemical and genetic identification of Aeromonas spp. APMIS 113, 203-207.

Saavedra, M. J., Figueras, M. J. \& Martínez-Murcia, A. J. (2006). Updated phylogeny of the genus Aeromonas. Int J Syst Evol Microbiol 56, 2481-2487.

Saitou, N. \& Nei, M. (1987). The neighbour-joining method: a new method for reconstructing phylogenetic trees. Mol Biol Evol 4, 406425.

Sepe, A., Barbieri, P., Peduzzi, R. \& Demarta, A. (2008). Evaluation of $r e c A$ sequencing for the classification of Aeromonas strains at the genotype level. Lett Appl Microbiol 46, 439-444.

Soler, L., Yañez, M. A., Chacón, M. R., Aguilera-Arreola, M. G., Catalán, V., Figueras, M. J. \& Martínez-Murcia, A. J. (2004). Phylogenetic analysis of the genus Aeromonas based on two housekeeping genes. Int J Syst Evol Microbiol 54, 1511-1519.

Stackebrandt, E. \& Ebers, J. (2006). Taxonomic parameters revisited: tarnished gold standards. Microbiol Today 33, 152-155.
Stackebrandt, E., Frederiksen, W., Garrity, G. M., Grimont, A. D, Kämpfer, P., Maiden, M. C. J., Nesme, X., Roselló-Mora, R., Swings, J. \& other authors (2002). Report of the ad hoc committee for the reevaluation of the species definition in bacteriology. Int J Syst Evol Microbiol 52, 1043-1047.

Swofford, D. L. (2002). PAUP*: Phylogenetic analysis using parsimony (* and other methods), version 4.0b10. Sunderland, MA: Sinauer Associates.

Tamura, K., Dudley, J., Nei, M. \& Kumar, S. (2007). MEGA4: Molecular evolutionary genetics analysis (MEGA) software version 4.0. Mol Biol Evol 24, 1596-1599.

Thompson, J. D., Higgins, D. G., Plewniak, F., Jeanmougin, F. \& Higgins, D. G. (1997). The CLUSTAL_X windows interface: flexible strategies for multiple sequence alignment aided by quality analysis tools. Nucleic Acids Res 25, 4876-4882.

Valera, L. \& Esteve, C. (2002). Phenotypic study by numerical taxonomy of strains belonging to the genus Aeromonas. J Appl Microbiol 93, 77-95.

Yáñez, M. A., Catalán, V., Apraiz, D., Figueras, M. J. \& MartínezMurcia, A. J. (2003). Phylogenetic analysis of members of the genus Aeromonas based on gyrB gene sequences. Int J Syst Evol Microbiol 53, 875-883. 